Web site: https://journal.djas.uodiyala.edu.iq/

ISSN: 2073-9524 (Print) https://dx.doi.org/10.52951/dasj.21130105

\title{
Effect of Pelleted Fermented Feed-in Egg Quality of Laying Hens
}

\author{
Hashim Hadi Dakhel Aljebory ${ }^{1}$ \\ Saad A.H. Naji ${ }^{2}$ \\ ${ }^{1}$ college of Agricultural Engineering Sciences- University of Baghdad \\ ${ }^{2}$ college of Agricultural Engineering Sciences- University of Baghdad \\ ${ }^{1}$ Corresponding author: hashem.hadi1101a@coagri.uobaghdad.edu.iq
}

\begin{abstract}
lactobacilli, Bacillus subtills, Bifidobacterium, Saccharomyces cerevisiae were applied to produce fermented feeds (FF), The FF was pelleted to investigated for its influences on egg quality for laying hens, the (FF) was ferment with $10 \mathrm{~g} / \mathrm{kg}$ feed of the probiotic with a wetting ratio of half a liter $/ \mathrm{kg}$ of feed for 48 hours where it was used at rates $0,25 \%, 50 \%, 75 \%$, and $100 \%$ for the treatments $\mathrm{T} 1, \mathrm{~T} 2, \mathrm{~T} 3, \mathrm{~T} 4$, and $\mathrm{T} 5$ respectively, and the duration of the study lasted for seven periods, each period was two weeks, as for the following study results: Significant superiority $(\mathrm{P} \leq 0.05)$ for all FF treatments during the second period and treatment T5 during the third and sixth periods, and for treatments T3, T4 and T5 during the fourth period in the shell weight. As for the shell thickness, a significant superiority $(\mathrm{P} \leq 0.01)$ was obtained for treatment T3 in the fourth period and for treatment T2 in the fifth, sixth, and seventh periods, and in the yolk height, there were a significant superiority $(\mathrm{P} \leq 0.01)$ for the treatment T4 during the first, second and seventh periods, and for the treatments T2 and T5 during the fourth and fifth periods, as for the yolk diameter, a significant superiority $(\mathrm{P} \leq 0.01)$ was obtained for the treatments $\mathrm{T} 2, \mathrm{~T} 3$ and $\mathrm{T} 4$ in the fourth and fifth periods, and $\mathrm{T} 2$ during the seventh period, and in albumen height, a significant $(\mathrm{P} \leq 0.01)$ was increased for the treatments $\mathrm{T} 3, \mathrm{~T} 4$, and $\mathrm{T} 5$ during the second period, and a significant superiority was obtained for treatment T5 in the fifth period and a significant superiority for the two treatments T1 and T2 in the seventh period.
\end{abstract}

Keyword: Egg quality, Fermentation feed, lying, Pelleting.

\section{Introduction}

The poultry industry is one of the fastest-growing animal industries in the world (Wang et al, 2017). Poultry meat and eggs are the most important source of dietary protein for the world population (Magdelaine, 2011). At the same time, the poultry industry faces some problems, including that egg production is now hampered by a shortage. Also, the layers of laying poultry projects aim to increase production to the maximum at the lowest cost (Godfray et al, 2010; Wang et al, 2017), as the problem

\footnotetext{
${ }^{1}$ The article is part of Ph.D. Thesis of the first author Dates:
}

Received: 04 March 2021 
of nutrition and mycotoxins remains in the first place considering the control of other conditions such as genetics and environmental conditions, may nutrition is the key to the aforementioned problems, as modern biotechnology provides new feeding methods to closely suit the nutritional needs of laying hens and mothers, thus reducing the cost of feed, which constitutes about $65-70 \%$ of the production cost (Nagy et al, 2016). Intensive egg production and mating or a weak immune system make birds vulnerable to disease (Cherian, 2013), and thus it became necessary to improve the quality of feed provided to birds to reach the best level of production. (FAOSTAT, 2015), fermentation technology is one of the most important techniques that improve the level of forage, as fermentation with the probiotic causes inhibition of the growth of pathogenic bacteria in the regimen of food (Cotter et al, 2013; Khan et al, 2020), increasing the protein content in it (El-Hag et al, 2002: Doudu et al, 2003; Pranoto et al, 2013) Besides, the fermentation process raise of the amino acids, inclusive methionine and lysine (Pranoto et al, 2013; Nkhata et al, 2018), which increases the absorbed and protein digested, by the bird. Fermentation increases the digestibility of FF grain protein (Yousif and El Tinayi, 2001 and 2003; Osman, 2004) as well as removes trypsin inhibitors (Osman, 2011) and reduces phytic (Osman, 2011; Hassan, 2015) and the production of organic acids (Van Immerseel et al., 2005). 2006), increased availability of mineral elements (Pranoto et al., 2013; Nkhata et al, 2018) as well as production of antioxidant vitamins (LeBlanc et al, 2011; Nagy et al, 2016) which is reflected in the productive and reproductive performance of laying hens. Among the novelty technologies for using a FF to convert it into the pellets to facilitate its storage, transportation, and handling (Yeh et al, 2018), the researcher indicated that it is can be to use an FF to reduce the price of feed due to the increase in the efficiency of using it, also for using the probiotic for fermentation of feed materials, also, the FF increase shell weight, eggs weight, and shell stiffness in laying hens are increased via fermented feed complement(Engberg et al, 2009). Meanwhile, Zhu et al, (2020) showed that feeding on fermented fodder improved the growth performance of laying hens, as well as the immune status by increasing the level of interleukins and the number of T- Lymphocyte, so the aims of a study to detect the effect of FF after the pelleting process in the eggs quality of the layer hens.

\section{Materials and methods}

\section{Ethical approval}

The Scientific Ethical Committee of College of Agricultural Engineering SciencesUniversity of Baghdad, Iraq approved this study (Approval no: (572); October 2020).

\section{Probiotics and Fermented Feed Preparation}

A commercial Iraqi probiotic content (lactobacilli, Bacillus subtills, Bifidobacterium, Saccharomyces cerevisiae used to ferment layer diet in table 1, aerobically fermentation with $10 \mathrm{~g}$ of a probiotic / $\mathrm{kg}$ of feed and a wetting ratio of half a liter of water/kg of feed for 48 hours after that the FF was dried and pelleted by pelleting machine.

\section{Experiment designing and chicken management}


This farm experiment was in the poultry farm of the Faculty of Agriculture/ AlQasim green University for 14 weeks extended for the period from Oct-28-2020 to Jan-27-2021, wherein this experiment the 58-week-old Lohman brown chicken was used, and 150 laying hens were randomly divided into five treatments, each treatment 30 chickens were divided into three replicates each of 10 chickens (T1: control treatment, T2: FF at a rate of $25 \%, \mathrm{~T} 3$ : FF at a rate of $50 \%, \mathrm{~T} 4: \mathrm{FF}$ at a rate of $75 \%$, $\mathrm{T} 5: \mathrm{FF}$ at a rate of $100 \%$ ), at seven periods each period of 2 weeks.

\section{Feed treatment}

The chickens were fed on ration below, a feed ration of $115 \mathrm{gm} / \mathrm{chicken} / \mathrm{day}$.

Table 1. The diet components in the study and their chemical composition

\begin{tabular}{|c|c|}
\hline Ingredients & $\%$ \\
\hline yellow corn & 36.5 \\
\hline wheat & 12 \\
\hline barley & 13.9 \\
\hline Soybean meal (44\% protein) & 25 \\
\hline Fremix & 2.5 \\
\hline DCP Calcium Diphosphate & 8.3 \\
\hline Sunflower oil & 1.8 \\
\hline Total** & 100 \\
\hline Metabolic energy (kilocalories/kg feed) & 2758.68 \\
\hline Crude protein $(\%)$ & 17.19 \\
\hline Crud fiber & 3.24 \\
\hline Calcium (\%) & 3.81 \\
\hline Available phosphorus (\%) & 0.29 \\
\hline Methionine + cysteine $(\%)$ & 0.73 \\
\hline Lysine $(\%)$ & 0.95 \\
\hline
\end{tabular}

*Premix Maxcare of Belgian origin Each $1 \mathrm{~kg}$ contains: crude protein 7.9\%, lysine 2.4\%, methionine $7.7 \%$, methionine + cysteine $(7.7 \%$ ), calcium $23.1 \%$, phosphorous $3.3 \%$, sodium $5.5 \%$, representative energy $(2903 \mathrm{kcal} / \mathrm{kg})$, vitamin A (400,000 IU), Vitamin D3 (300,000 IU), Vitamin D (20,000 IU), Vitamin E (800 IU), Vitamin K 80 ppm, Vitamin B1 40 ppm, Vitamin B2 (1600) ppm, Calcium Pantothenate (320) ppm, Niacin (600) ppm, Biotin (1600) ppb, vitamin B12(1000) ppb, folic acid (40) ppm, vitamin B6 (160) ppm, iron $2800 \mathrm{ppm}$, copper 600 ppm, zinc (2400) ppm, magnesium (4000) ppm, iodine (80) ppm, selenium 8 ppm.

** Chemical analysis computed according to NRC (1994)

- Dicalcium phosphate with a concentration of calcium in $24 \%$, phosphorus $18 \%$. 
- (9000) kcal/kg oil

\section{Studied traits}

\section{Yolk and albumen height}

Later than the egg was broken on a flat surfacing, the rising of the yolk and albumen was measured by a special three-base micrometer device (Ames micrometer), and a mean of two readings of the albumen of each egg were taken from the area close to the contact of the thick white with the yolk (Wilgus and Van Wangener, 1936). The height of the yolk was measured from the center after breaking the egg on a flat surface. The diameter of the yolk was also measured with a special Vernia, where the eggs were taken randomly and for all the replicates, and the height of the yolk was taken from the center. As for the height of the albumen, it was taken from the center and the far end, after which the rate was taken.

\section{Shell thickness}

Measure the thickness of a shell with the inner membranes, after deriding it from the tapered and convex sides of each egg with a micrometer device, where he taking two readings for the pointed side and the wide side average of the two readings, according to the equation below:

\section{Shell Thickness of First End (mm) + Shell Thickness of Second End (mm)} shell thickness $=$

$(\mathrm{Mm})$

\section{Shell Weight (g)}

Use a sensor scale for this, which reads to two decimal places, where the shell was weighed with its membranes after emptying the entire contents of the eggs.

\section{statistical analysis}

The Statistical Analysis System -SAS (2012) was used in data analysis to study the effect of different treatments on the traits studied according to a Completely Randomized Design (C.R.D), and the mean differences among the treatments were compared according to Duncan multiple ranges test (Duncan,1955).

$Y i j=\mu+T i+\varepsilon i j$

Yij: The observation $\mathrm{j}$ of treatment $\mathrm{i}$.

$\mu$ : Overall mean.

Ti: effect of treatment $i$ (the study included the impact of five treatments).

Eij: a random error that is normally distributed with an average of zero and a variation of $\sigma 2 \mathrm{e}$ 


\section{Results and Discussion}

\section{Shell weight}

Table 2 shows the effect of the treatments on the eggshell weight the eggshell produced. It is noticed that there are no significant differences between the studied treatments during the first, third, and seventh periods. In the second period, significant superiority was observed $(\mathrm{P} \leq 0.05)$ for all FF treatments compared with the control treatment, and there was no large difference. Among the treatments T2, T3, T4, and $\mathrm{T} 5$, and in the fourth period, a significant superiority was obtained $(\mathrm{P} \leq 0.05)$ for the treatment $\mathrm{T} 5$ compared to the two cases $\mathrm{T} 1$ and $\mathrm{T} 4$, and there was no large difference among the treatments T2, T3, and T5 and also among the treatments T1, T2, T3, and T4. The fifth period showed significant superiority $(\mathrm{P} \leq 0.05)$ for the treatments of $\mathrm{T} 3$, T4, and T5 compared to the treatment T1. No significant difference was recorded among the treatments of T2, T3, T4, and T5 as well between the two treatments of T1 and $\mathrm{T} 2$. In the sixth period, a significant superiority $(\mathrm{P} \leq 0.05)$ was observed for the treatment. T5 compared to the rest of the treatments, and there was no a large difference among the treatments of $\mathrm{T} 1, \mathrm{~T} 2, \mathrm{~T} 3$, and $\mathrm{T} 4$.

\section{Shell thick (mm)}

Table 3 indicates the impact of the treatments on the eggshell thickness the eggshell, and it is noticed during the first, second and third periods that there are no a large differences between the treatments, while in the fourth period, a significant notability $(\mathrm{P} \leq 0.01)$ for treatment $\mathrm{T} 3$ compared to treatment $\mathrm{T} 1$ and there are no significant differences between the treatments T2, T3, T4, T5 and also between the treatments of T1, T2, T4, T5 and in the second and eighth period, a significant superiority $(\mathrm{P} \leq 0.01)$ was observed for treatment $\mathrm{T} 2$ compared to treatment of $\mathrm{T} 1$ and there were no significant differences between the treatments T1, T3, T4, T5 as well as between the treatments of $\mathrm{T} 2 \mathrm{~T} 3, \mathrm{~T} 4, \mathrm{~T} 5$ and the significant superiority $(\mathrm{P} \leq 0.01)$ of treatment T2 withdrew in the sixth period compared to the two treatments T1, T3 and the superiority of the treatments of $\mathrm{T} 3, \mathrm{~T} 4, \mathrm{~T} 5$ over treatment of $\mathrm{T} 1$, and no a large differences were found between the treatments for treatment $\mathrm{T} 2$ through the seventh period compared to the treatments $\mathrm{T} 1, \mathrm{~T} 3, \mathrm{~T} 5$, and $\mathrm{T} 4$ outperformed treatment $\mathrm{T} 1$ and $\mathrm{T} 3$, and no a large differences were found between the treatments $\mathrm{T} 2$ and $\mathrm{T} 4$, as well as between the treatments $\mathrm{T} 1, \mathrm{~T} 3, \mathrm{~T} 5$ and also between the two treatments of theT4 and $\mathrm{T} 5$.

\section{Yolk height}

Table 4 shows the effect of the treatments on the yolk height of the eggs produced during the study period. It is noticed during the first and second periods that a significant $(\mathrm{P} \leq 0.01)$ was obtained for treatment $\mathrm{T} 4$ compared to the treatments $\mathrm{T} 1, \mathrm{~T} 2$, and T5Noa large differences were found between the treatments T3 and T4 as well as between the treatments T1, T2, T3, and T5, also in the third and sixth periods, there was no significant difference among the studied treatments, but in the fourth and fifth periods, it was lucid that there was a significant superiority $(\mathrm{P} \leq 0.01)$ for the treatments $\mathrm{T} 2$ and $\mathrm{T} 5$ compared to the treatments $\mathrm{T} 1$ and $\mathrm{T} 4$, and there was no significant difference between the treatments $\mathrm{T} 2, \mathrm{~T} 3$ and $\mathrm{T} 5$ also the treatments $\mathrm{T} 1$, 
$\mathrm{T} 3$, and $\mathrm{T} 4$. In the seventh period, there was a large superiority $(\mathrm{P} \leq 0.01)$ for treatment $\mathrm{T} 4$ compared to the treatments $\mathrm{T} 1, \mathrm{~T} 2$, and T5, and for the treatments $\mathrm{T} 3$, T5 over the treatments $\mathrm{T} 1$ and $\mathrm{T} 2$, and there was no a large difference between the treatments $\mathrm{T} 1$, $\mathrm{T} 2$ and the treatments $\mathrm{T} 3$ and $\mathrm{T} 5$ as well as the treatments $\mathrm{T} 3$ and $\mathrm{T} 4$. 
Table 2. Mean \pm standard error of the effect of fermented food in the eggshell weight (gm)

\begin{tabular}{|c|c|c|c|c|c|c|c|}
\hline \multirow[t]{2}{*}{ Treatments } & \multicolumn{7}{|c|}{ Means \pm standard error $(\mathrm{gm})$} \\
\hline & first period & Second period & Third period & Fourth period & Fifth period & Sixth period & Seventh period \\
\hline $\mathrm{T} 1$ & $0.086 .36 \pm$ & b6.29 \pm 0.06 & $0.256 .31 \pm$ & $0.24 \mathrm{~b} 6.41 \pm$ & $0.06 \mathrm{~b} 6.21 \pm$ & $0.08 \mathrm{~b} \pm 6.43$ & $0.05 \pm 6.52$ \\
\hline $\mathrm{T} 2$ & $0.086 .53 \pm$ & a6.66 \pm 0.07 & $0.136 .57 \pm$ & $0.06 \mathrm{ab} 6.71 \pm$ & $\begin{array}{c}0.12 \\
\mathrm{ab} \pm 6.52\end{array}$ & 0.13 b6.58 & $0.196 .73 \pm$ \\
\hline T3 & $0.126 .76 \pm$ & $\mathrm{a} 6.69 \pm 0.08$ & $0.296 .72 \pm$ & $0.07 \mathrm{ab} 6.77 \pm$ & $0.04 \mathrm{a} 6.62 \pm$ & $0.22 \mathrm{~b} 6.98 \pm$ & $0.126 .86 \pm$ \\
\hline $\mathrm{T} 4$ & $6.61 \pm 0.04$ & $\mathrm{a} 6.57 \pm 0.06$ & $0.356 .74 \pm$ & $0.11 \mathrm{~b} 6.29 \pm$ & $0.12 \mathrm{a} 6.67 \pm$ & $0.10 \mathrm{~b} 6.77 \pm$ & $0.046 .81 \pm$ \\
\hline T5 & $6.56 \pm 0.21$ & $\mathrm{a} 6.53 \pm 0.07$ & $0.056 .83 \pm$ & $0.15 \mathrm{a} 6.96 \pm$ & $0.12 \mathrm{a} 6.63 \pm$ & 0.04 a $7.87 \pm$ & $0.066 .87 \pm$ \\
\hline Significant & N.S & $*$ & N.S & $*$ & $*$ & $*$ & N. S \\
\hline
\end{tabular}

Means with different letters indicate a significant difference in probability level 0.05, N. S: Not significant * $(\mathrm{P} \leq 0.05)$. The treatment T1, T2, T3, T4, T5 are control treatments without addition, adding $25 \%, 50 \%, 75 \%, 100 \%$ fermented feed, respectively. 
Table 3. Mean \pm standard error of the effect of fermented food in the eggshell thickness $(\mathbf{m m})$

\begin{tabular}{|c|c|c|c|c|c|c|c|}
\hline \multirow{2}{*}{ Treatments } & \multicolumn{7}{|c|}{ Means \pm standard error (mm) } \\
\cline { 2 - 7 } & first period & Second period & Third period & Fourth period & Fifth period & Sixth period & Seventh period \\
\hline T1 & \pm 0.090 .50 & $0.050 .41 \pm$ & $0.050 .40 \pm$ & $0.01 \mathrm{~b} 0.42 \pm$ & $0.08 \mathrm{~b} 0.43 \pm$ & $0.02 \mathrm{c} \pm 0.36$ & $\mathrm{c} \pm 0.010 .43$ \\
\hline T2 & $0.080 .41 \pm$ & $0.010 .41 \pm$ & $0.030 .45 \pm$ & $0.01 \mathrm{ab} 0.48 \pm$ & $0.02 \mathrm{a} \pm 0.57$ & $0.15 \mathrm{a} 0.52 \pm$ & $0.01 \mathrm{a} 0.56 \pm$ \\
\hline T3 & $0.030 .49 \pm$ & $0.080 .43 \pm$ & $0.030 .41 \pm$ & $0.03 \mathrm{a} 0.55 \pm$ & $0.01 \mathrm{ab} 0.50 \pm$ & $0.02 \mathrm{~b} 0.44 \pm$ & $0.07 \mathrm{c} 0.45 \pm$ \\
\hline T4 & $0.060 .53 \pm$ & $0.020 .43 \pm$ & $0.060 .44 \pm$ & $0.04 \mathrm{ab} 0.50 \pm$ & $0.05 \mathrm{ab} 0.54 \pm$ & $0.09 \mathrm{ab} 0.48 \pm$ & $0.06 \mathrm{ab} 0.52 \pm$ \\
\hline T5 & $0.050 .51 \pm$ & $0.010 .44 \pm$ & $0.040 .46 \pm$ & $0.02 \mathrm{ab} 0.51 \pm$ & $0.05 \mathrm{ab} 0.50 \pm$ & $0.02 \mathrm{ab} 0.49 \pm$ & $0.08 \mathrm{bc} 0.47 \pm$ \\
\hline Significant & N. S & N. S & N. S & $* *$ & $* *$ & $* *$ & $* *$ \\
\hline
\end{tabular}

Means with different letters indicate a significant difference in probability level $0.05, \mathrm{~N}$. S: Not significant ** $(\mathrm{P} \leq 0.01)$. The treatment T1, T2, T3, T4, T5 are control treatments without addition, adding $25 \%, 50 \%, 75 \%, 100 \%$ fermented feed, respectively. 


\section{Yolk diameter}

Table 5 shows the effect of the treatments on the diameter of the egg yolk produced during the trial period, and it is noticed that there are no significant differences between the studied treatments in the first, second, third, and sixth periods. In the fourth period, significant superiority $(\mathrm{P} \leq 0.01)$ was obtained for the treatments of T2, T3, T4 Compared with the treatment of T1, there was no significant difference between the treatments of $\mathrm{T} 2, \mathrm{~T} 3, \mathrm{~T} 4$, and $\mathrm{T} 5$, as well as between the treatments $\mathrm{T} 1$ and $\mathrm{T} 5$. In the fifth period, it was found that there was a large superiority $(\mathrm{P} \leq 0.01)$ for the treatments of 2 and $\mathrm{T} 4$ compared to the treatments of $\mathrm{T} 1$ and T5, and there was no significant difference between the treatments of theT2, T3, $\mathrm{T} 4$, and also between the treatments $\mathrm{T} 1, \mathrm{~T} 3$, and $\mathrm{T} 5$ and the significant superiority $(\mathrm{P} \leq 0.01)$ of treatment of $\mathrm{T} 2$ continued during the seventh period compared to the treatments of $\mathrm{T} 1, \mathrm{~T} 3, \mathrm{~T} 4$ and the treatment $\mathrm{T} 5$ superiority the treatments $\mathrm{T} 1$ and $\mathrm{T} 4$ and the treatments $\mathrm{T} 3$ and $\mathrm{T} 4$ exceeded the treatment $\mathrm{T} 1$ and did not There was no a large difference between the treatments $\mathrm{T} 2$ and $\mathrm{T} 5$, as well as between the treatments $\mathrm{T} 3$ and T5, and also between a treatments ofT3, T4.

\section{Albumin height}

$\mathrm{T}$ is noted from table 6 the effect of the treatments on the albumin height during the trial period, and there was no a large difference among treatments during the first, third, fourth, and sixth periods, while in the second period, a significant superiority appeared $(\mathrm{P} \leq 0.01)$ for the treatments of $\mathrm{T} 3, \mathrm{~T} 4$, and $\mathrm{T} 5$ compared to with the treatments $\mathrm{T} 1$ and $\mathrm{T} 2$, there was no a large difference between the treatments of $\mathrm{T} 1$, $\mathrm{T} 2$, as well as among the treatments of T3, T4, and T5. There was a significant difference between the treatments $\mathrm{T} 2, \mathrm{~T} 3$, and T5 and also between treatments of $\mathrm{T} 2$, $\mathrm{T} 3$, T4, and in the seventh-period significant superiority appeared $(\mathrm{P} \leq 0.01)$ for the treatments $\mathrm{T} 1$ and $\mathrm{T} 2$ compared to the treatments $\mathrm{T} 3, \mathrm{~T} 4$, and $\mathrm{T} 5$, also there was no a large difference between the two treatments $\mathrm{T} 1$ and $\mathrm{T} 2$, as well as among treatments of T3, T4, and T5.

The improvement in the peel qualities of the fermented fodder treatments may be due to the feeding on the FF, as the fermentation of the fodder results in a higher protein 
Table 4. Mean \pm standard error of the effect of fermented food in the yolk height $(\mathrm{mm})$

\begin{tabular}{|c|c|c|c|c|c|c|c|}
\hline \multirow{2}{*}{ Treatments } & \multicolumn{7}{|c|}{ Average \pm standard error $(\mathrm{mm})$} \\
\cline { 2 - 8 } & first period & Second period & Third period & Fourth period & Fifth period & Sixth period & Seventh period \\
\hline $\mathrm{T} 1$ & $0.57 \mathrm{~b} \pm 15.03$ & $0.55 \mathrm{~b} \pm 15.00$ & $0.53 \pm 15.30$ & $0.14 \mathrm{~b} \pm 14.03$ & $0.29 \mathrm{~b} \pm 14.77$ & $0.54 \pm 15.60$ & $0.30 \mathrm{c} \pm 13.90$ \\
\hline $\mathrm{T} 2$ & $0.90 \mathrm{~b} \pm 15.87$ & $0.57 \mathrm{~b} \pm 16.00$ & $0.74 \pm 15.73$ & $0.28 \mathrm{a} \pm 16.64$ & $0.63 \mathrm{a} \pm 16.97$ & $0.07 \pm 16.28$ & $0.32 \mathrm{c} \pm 14.77$ \\
\hline $\mathrm{T} 3$ & $1.05 \mathrm{ab} \pm 17.28$ & $0.88 \mathrm{ab} \pm 16.66$ & $0.64 \pm 16.21$ & $0.92 \mathrm{ab} \pm 15.43$ & 0.74 & $0.88 \pm 16.20$ & $0.12 \mathrm{ab} \pm 16.13$ \\
\hline $\mathrm{T} 4$ & $0.75 \mathrm{a} \pm 18.71$ & $0.33 \mathrm{a} \pm 18.66$ & $1.04 \pm 15.31$ & $0.20 \mathrm{~b} \pm 15.05$ & $0.06 \mathrm{~b} \pm 15.03$ & $0.10 \pm 15.46$ & $0.28 \mathrm{a} \pm 16.64$ \\
\hline T5 & $0.13 \mathrm{~b} \pm 15.27$ & $1.45 \mathrm{~b} \pm 15.66$ & $0.69 \pm 15.34$ & $0.02 \mathrm{a} \pm 16.56$ & $0.18 \mathrm{a} \pm 17.47$ & $0.27 \pm 16.26$ & $0.48 \mathrm{~b} \pm 15.87$ \\
\hline Significant & $* *$ & $* *$ & N. S & $* *$ & $* *$ & $\mathrm{~N} . \mathrm{S}$ & $* *$ \\
\hline
\end{tabular}

Means with different letters indicate a significant difference in probability level 0.05, N. S: Not significant ** $(\mathrm{P} \leq 0.01)$. The treatment T1, T2, T3, T4, T5 are control treatments without addition, adding $25 \%, 50 \%, 75 \%, 100 \%$ fermented feed, respectively. 
Table 5. Mean \pm standard error of the effect of fermented food in the yolk diameter $(\mathrm{mm})$

\begin{tabular}{|c|c|c|c|c|c|c|c|}
\hline \multirow{2}{*}{ Treatments } & \multicolumn{7}{|c|}{ Average \pm standard error } \\
\cline { 2 - 8 } & first period & Second period & Third period & Fourth period & Fifth period & Sixth period & Seventh period \\
\hline T1 & $3.18 \pm 40.08$ & $0.40 \pm 39.78$ & $1.55 \pm 40.35$ & $1.27 \mathrm{~b} \pm 40.65$ & $0.90 \mathrm{~b} \pm 40.18$ & $0.20 \pm 40.05$ & $0.55 \mathrm{~d} \pm 39.77$ \\
\hline T2 & $1.72 \pm 40.69$ & $0.91 \pm 41.45$ & $1.37 \pm 41.77$ & $0.70 \mathrm{a} \pm 43.82$ & $0.07 \mathrm{a} \pm 42.76$ & $0.68 \pm 41.62$ & $0.09 \mathrm{a} \pm 42.77$ \\
\hline T3 & $0.34 \pm 38.57$ & $0.40 \pm 41.03$ & $0.71 \pm 42.31$ & $0.47 \mathrm{a} \pm 43.19$ & 0.20 & $0.27 \pm 40.96$ & $0.35 \mathrm{bc} \pm 41.78$ \\
\hline T4 & $0.85 \pm 40.52$ & $0.32 \pm 40.32$ & $0.55 \pm 42.46$ & $0.84 \mathrm{a} \pm 43.15$ & $0.35 \mathrm{a} \pm 42.74$ & $0.66 \pm 41.03$ & $0.10 \mathrm{c} \pm 41.28$ \\
\hline T5 & $0.50 \pm 41.28$ & $1.66 \pm 40.84$ & $0.47 \pm 40.87$ & $0.69 \mathrm{ab} \pm 41.72$ & $0.16 \mathrm{~b} \pm 40.15$ & $0.45 \pm 41.57$ & $0.26 \mathrm{ab} \pm 42.57$ \\
\hline Significant & N. S & N. S & N. S & $* *$ & $* *$ & N. S & $* *$ \\
\hline
\end{tabular}

Means with different letters indicate a significant difference in probability level $0.05, \mathrm{~N}$. S: Not significant $* *(\mathrm{P} \leq 0.01)$. The treatment T1, T2, T3, T4, T5 are control treatments without addition, adding $25 \%, 50 \%, 75 \%, 100 \%$ fermented feed, respectively. 
content (El-Hag et al. 2002: Doudu et al. 2003; Pranoto et al. 2013). Besides, the fermentation process increases the amino acids, including methionine and lysine (Pranoto et al., 2013; Nkhata et al., 2018), which increases the protein digested and absorbed by the chicken, as well as the fermentation process increases the digestibility of forage grain protein (Yousif and El Tinayi, 2001 and 2003; Osman, 2004) They also remove trypsin inhibitors (Osman, 2011) and reduce phytic (Osman, 2011; Hassan, 2015) by activating the phytase enzyme, which increases the efficiency of utilizing the absorbed nutrients, which is reflected in the quality of the eggs produced by the chicken and the internal characteristics of the egg, Also, probiotic bacteria produce organic acids (Van Immerseel et al., 2006). These acids are produced by decomposing carbohydrates, thus reducing the $\mathrm{pH}$ of the feed and the chicken's intestine, and that lowering the intestinal ph improves the quality of egg albumin (Tortuero and Fernandez, 1995; Gallazzi et al, 2008), and the improvement in the quality of the shell may be caused by the fermentation of fodder, whereas a result of fermentation, the bioavailability of the mineral elements will increase. Available and not digested by the chicken's digestive enzymes (Nkhata et al., 2018) and that fermentation increases the availability of mineral elements for FF as it found an increase in the level of calcium, magnesium, iron, and zinc after fermentation (Pranoto et al., 2013) also the fermentation increases the availability of calcium, phosphorus, and iron due to decomposition the phytates and oxalates, which chicken to minerals and reduce their bioavailability (Sripriya et al., 1997). Also, amylase and phytase enzymes act on the excretion of probiotic bacteria during the fermentation process, which degrades carbohydrates and phytates, which increases the availability of phosphorous (Liang et al., 2008), all of these factors mentioned above improvement of shell weight and thickness in FF treatments, as well as a decrease in $\mathrm{pH}$ during the fermentation process. Aided in the absorption of mineral elements, causing phytic degradation and increasing phosphorous availability (Hemalatha et al. 2007; Reale et al., 2007). As Khan et al, (2020), have shown the enhanced bacteria improve the quality of eggs and their shells by increasing the efficiency of calcium transport through the wall of the gastrointestinal tract as well as compensating for the deficiency of minerals. Saccharomyces cerevisiae also produces a protein (Ferreira et al., 2010; Day, 2016). It was found that it increased the proportion of protein and mineral elements when fermenting corn (Day and Ruben, 2018). The fermented forage materials have a higher digestibility than the thermally treated forage materials (Duodu et al. 2003; Day and Ruben, 2018). Then drying it, after that, it is exposed to heat as a result of converting it into pellets, which will further break the bonds between the nutrients and thus be more available to the bird. Thus, this process is considered one of the most promising technologies in the poultry feed industry. 
Table 6. Mean \pm standard error of the effect of fermented food in the albumen height $(\mathrm{mm})$

\begin{tabular}{|c|c|c|c|c|c|c|c|}
\hline \multirow{2}{*}{ Treatments } & \multicolumn{7}{|c|}{ Average \pm standard error $(\mathrm{mm})$} \\
\cline { 2 - 7 } & first period & Second period & Third period & Fourth period & Fifth period & Sixth period & Seventh period \\
\hline $\mathrm{T} 1$ & $0.14 \pm 3.76$ & $0.12 \mathrm{~b} \pm 3.67$ & $0.04 \pm 4.42$ & $0.11 \pm 5.61$ & $0.17 \mathrm{c} \pm 4.87$ & $0.06 \pm 5.99$ & $0.49 \mathrm{a} \pm 6.62$ \\
\hline $\mathrm{T} 2$ & $0.33 \pm 4.33$ & $0.22 \mathrm{~b} \pm 3.83$ & $0.76 \pm 4.78$ & $0.16 \pm 6.63$ & $0.17 \mathrm{ab} \pm 6.06$ & $0.14 \pm 5.80$ & $0.20 \mathrm{a} \pm 6.47$ \\
\hline T3 & $0.47 \pm 4.23$ & $0.06 \mathrm{a} \pm 5.21$ & $0.20 \pm 4.73$ & $0.38 \pm 6.14$ & $0.16 \mathrm{ab} \pm 6.32$ & $0.20 \pm 6.51$ & $0.48 \mathrm{~b} \pm 5.01$ \\
\hline T4 & $0.34 \pm 4.35$ & $0.09 \mathrm{a} \pm 4.58$ & $0.29 \pm 4.72$ & $0.58 \pm 6.61$ & $0.29 \mathrm{~b} \pm 5.62$ & $0.03 \pm 6.45$ & $0.21 \mathrm{~b} \pm 5.30$ \\
\hline T5 & $0.33 \pm 4.33$ & $0.36 \mathrm{a} \pm 4.96$ & $0.42 \pm 5.28$ & $0.71 \pm 5.81$ & $0.31 \mathrm{a} \pm 6.48$ & $0.47 \pm 6.20$ & $0.03 \mathrm{~b} \pm 5.14$ \\
\hline Significant & N. S & $* *$ & N. S & N. S & $* *$ & N. S \\
\hline
\end{tabular}

Means with different letters indicate a significant difference in probability level $0.05, \mathrm{~N}$. S: Not significant. ** $(\mathrm{P} \leq 0.01)$. The treatment T1, T2, T3, T4, T5 are control treatments without addition, adding $25 \%, 50 \%, 75 \%, 100 \%$ fermented feed, respectively. 


\section{Conclusions}

The fermentation of feed with probiotic and converting it into a pellet is one of the promising industries in poultry feeding, where fermentation and heat in the pelleting process reach the best level of crushing and digestion of nutrients and thus reaching the maximum benefit by the birds.

\section{Conflict of interest}

there is no conflict of interest between authors

\section{Acknowledgments}

The authors thank the college of agriculture- Al- Qasim green university for their assistance in conducting the research, as well as the staff of scientific laboratories in it, as well as the Al-Barakah Milling in Babel Government.

\section{References}

Cherian, G. 2013. Keynote symposium: "tomorrow's poultry: sustainability and safety" introduction and welcome. Poult Sci. 92:492.

Cotter PD, Ross RP, Hill C. 2013. Bacteriocins - a viable alternative to antibiotics? Nat Rev Microbiol 11:95-105. https://doi.org/10.1038/ nrmicro2937.

Day, C, N. and Ruben O. Morawicki. 2018. Effects of Fermentation by Yeast and Amylolytic Lactic Acid Bacteria on Grain Sorghum Protein Content and Digestibility. Journal of Food Quality Volume 2018, Article ID 3964392, 8 pages https://doi.org/10.1155/2018/3964392.

Day, C. 2016. Effects of fermentation by yeast and amylolytic lactic acid bacteria on grain sorghum protein content and digestibility," Teses and Dissertations 1843, http://scholarworks.uark .edu/etd/1843.

Doudu, K. G., Taylor, J. R. N., Belton, P. S., \& Hamaker, B. R. 2003. Factors affecting sorghum protein digestibility. Journal of Cereal Science, 38, 117-131. https://doi.org/10.1016/S0733-5210(03)00016-X .

Duncan, D.B., 1955. Multiple ranges and multiple F tests. Biometrics $11: 1-42$.

El-Hag, M. E., El-Tinay, A. H., \& Yousif, N. E. 2002. Effect of fermentation and dehulling on starch, total polyphenols, phytic acid content and in vitro protein digestibility of pearl millet. Food Chemistry, 77, 193-196. https://doi.org/10.1016/S0308-8146(01)00336-3.

Engberg, R. M., M. Hammershoj, N. F. Johansen, M. S. Abousekken,S. Steenfeldt, \& B. B. Jensen. 2009. Fermented feed for laying hens: effects on egg production, egg quality, plumage condition and composition and activity of the intestinal microflora. Br. Poult. Sci.50:228-239.

FAOSTAT. 2015. Food and agricultural organization statistics database (FAOSTAT). http://www.fao.org. 
Ferreira, I. M. P. L. V. O. O. Pinho, E. Vieira, \& J. G. Tavarela. 2010. Brewer's Saccharomyces yeast biomass: characteristics and potential applications," Trends in Food Science \& Technology, vol. 21, no. 2, pp. 77-84.

Gallazzi, D. Giardini, A.; Mangiagalli, M. G.; Marelli, S.; Ferrazzi, V.; Orsi, C.; Cavalchini, L. G. 2009. Effects of Lactobacillus acidophilus D2/CSL on laying hen performance. Italian Journal of Animal Science 7: 27-38.

Gallazzi, D. Giardini, A. Mangiagalli, M. G.; Marelli, S.; Ferrazzi, V.; Orsi, C.; Cavalchini, L. G., 2008. Effects of Lactobacillus acidophilus D2/CSL on laying hen performance. Italian Journal of Animal Science 7. 27-38.

Godfray H. C. J., Beddington JR, Crute IR, Haddad L, Lawrence D, Muir JF.2010. Food security: the challenge of feeding 9 billion people. Science $.327: 812 \mathrm{e} 8$.

Hassan, G. F., Yusuf, L., Adebolu, T. T., \& Onifade, A. K. 2015. Effect of fermentation on mineral and anti-nutritional composition of cocoyam (Colocasia esculenta linn). Sky Journal of Food Science, 4, 042-049.

Hemalatha, S., Platel, K., \& Srinivasan, K. 2007. Influence of germination and fermentation on bioaccessibility of zinc and iron from food grains. European Journal of Clinical Nutrition, 61, 342-348. https://doi. org/10.1038/sj.ejen.1602524.

Khan, A. Robert J. Moore, B Dragana Stanley, C Kapil K. Chousalkara. 2020. The Gut Microbiota of Laying Hens and Its Manipulation with Prebiotics and Probiotics To Enhance Gut Health and Food Safety Samiullah. Applied and Environmental Microbiology. Volume 86 Issue 13 . doi.org/10.1128/AEM $.00600-20$.

LeBlanc J. G, Laino JE, Juarez del Valle M, Vannini V, Van Sinderen D, Taranto MP, Font de Valdez G, Savoy de Giori G, Sesma F .2011. B-Group vitamin production by lactic acid bacteria-current knowledge and potential applications. Journal of Applied Microbiology 111-6.

Liang, J., Han, B. Z., Nout, M. J. R., \& Hamer, R. J. 2008. Effects of soaking, germination and fermentation on phytic acid, total and in vitro soluble zinc in brown rice. Food Chemistry, 110, 821-828. https://doi. org/10.1016/j.foodchem.2008.02.064.

Magdelaine, P. 2011. Egg and egg product production and consumption in Europe and the rest of the world. In: Improving the safety and quality of eggs and egg products: egg chemistry production and consumption, vol. 207. p. 3e16.

Naji, Saad Abd Al-Hussein, Ziad Tariq Al-Dhanaki, Ghaleb Alwan Al-Qaisi, and Walid Razzouki. 2007. A guide to commercial production of broiler mothers. For the Iraqi Federation of Poultry Producers. Poultry Science Association. Technical Bulletin .16.

Nagy G, Pinczes G, Pinter G, Posci I, Prokisch J, Banfalvi G .2016. In-situ electron microscopy of lactomicroselenium particles in probiotic bacteria. International Journal of Molecular Science 17:1047. 
N.R.C . National Research Council 1994 . Nutrient Requirements of poultry . $9^{\text {th }}$ ed., National Academic press . Washington . DC., USA . PP . 120.

Nkhata, S.G. Ayua, E. Kamau, E.H. Shingiro, J.B. 2018. Fermentation and germination improve nutritional value of cereals and legumes through activation of endogenous enzymes. Food Sci. Nutr. 6, 2446-2458.

Osman, M. A. 2004. Changes in sorghum enzyme inhibitors, phytic acid, tannins and in vitro protein digestibility occurring during Khamir (local bread) fermentation. Food Chemistry, 88, 129-134. https://doi. org/10.1016/j.foodchem.2003.12.038.

Osman, M. A. 2011. Effect of traditional fermentation process on the nutrient and antinutrient contents of pearl millet during preparation of Lohoh. Journal of the Saudi Society of Agricultural Sciences, 10, 1-6.

Pranoto, Y., Anggrahini, S., \& Efendi, Z. 2013. Effect of natural and Lactobacillus plantarum fermentation on invitro protein and starch digestibilities of sorghum flours. Food Bioscience, 2, 46-52. https:// doi.org/10.1016/j.fbio.2013.04.001.

Reale, A., Konietzny, U., Coppola, R., Sorrentino, E., \& Greiner, R. 2007. The importance of lactic acid bacteria for phytate degradation during cereal dough fermentation. Journal of Agricultural and Food Chemistry, 55, 2993-2997. https://doi.org/10.1021/jf063507n.

SAS, 2012. Statistical Analysis System, User's Guide. Statistical. Version $9.1^{\text {th }}$ ed. SAS. Inst. Inc. Cary. N.C. The USA.

Sripriya, G., Antony, U., \& Chandra, T. S. 1997. Changes in carbohydrate, free amino acids, phytate and HCL extractability of minerals during germination and fermentation of finger millet (Eleusine coracana). Food Chemistry, 58, 345-350. https://doi.org/10.1016/S0308-8146(96)00206-3.

Tortuero, F., Fernández, E., 1995. Effects of inclusion of microbial cultures in barleybased diets fed to laying hens. Anim. Feed. Sci. Tech. 53:255-265.

Van Immerseel, F., Russell, J. B., Flythe, M. D., Gantois, I., Timbermont, L., Pasmans, F., Haesebrouck, F., \& Ducatelle, R. 2006. The use of organic acids to combat Salmonella in poultry, a mechanistic explanation of the efficacy. Avian Pathology, 35, 182-188.

Wang, J., Hongyuan Yue, Shugeng Wu, Haijun Zhang, Guanghai Qi. 2017. Nutritional modulation of health, egg quality and environmental pollution of the layers. Animal Nutrition 3-91e96. doi.org/10.1016/j.aninu.2017.03.001.

Wilgus , H. and A. Van Wangener . 1936. The height of firl albumen as measure of its condition. Poultry Science. 15: 319-321.

Yeh R. H, Chia-Wen Hsieh, and Kuo Lung Chen. 2018. Screening lactic acid bacteria to manufacture two-stage fermented feed and pelleting to investigate the feeding effect on broilers. Poultry Science 97:236-246.

http://dx.doi.org/10.3382/ps/pex300. 
Yousif, N. E., \& El Tinayi, A. H. 2001. Effect of fermentation on sorghum protein fractions and in vitro protein digestibility. Plant Foods for Human Nutrition, 56, 175-182. https://doi. org/10.1023/A:1011140602122.

Yousif, N. E., \& El Tinayi, A. H. 2003. Effect of natural fermentation on protein fractions and in vitro protein digestibility of rice. Plant Foods for Human Nutrition, 58, 1-8.

Zhu, F., Beibei Zhang, Jin Li,y and Lianqin Zhuy. 2020. Effects of fermented feed on growth performance, immune response, and antioxidant capacity in laying hen chicks and the underlying molecular mechanism involving nuclear factor-kB. Poultry Science 99:2573-2580. https://doi.org/10.1016/j.psj.2019.12.044 